\title{
Italy backs Third World science body ...
}

[TRIESTE] The Italian government announced last week that it has agreed to make a longterm financial commitment to the Third World Academy of Sciences (TWAS), the body set up in 1983 at the initiative of the late physicist and Nobel laureate Abdus Salam.

According to academy officials, the move should allow the academy to significantly increase its operating budget within the next few years, boosting its efforts to stimulate scientific excellence in Third World countries.

The academy was set up by Salam alongside the International Centre for Theoretical Physics (ICTP) in Trieste, of which he was director from its foundation in 1964 until 1993. From an initial membership of 44 , it now has more than 400 full members, each recognized for scientific achievement.

Until now, the operating costs of the academy have been largely covered by an annual grant from the Italian government. But the value of this has dropped considerably in recent years, and Italy's financial instability has also created problems.

Under an agreement signed last week, however, the government has promised to present a bill to parliament committing it to increase its payments to the academy from 1.9 billion lire (US $\$ 1.16$ million) next year to 3 billion lire in three years' time, and to maintain it at that level thereafter, subject to a biannual review.

This will provide the academy with the

\section{... as African women get research career boost}

[TRIESTE] The Third World

Academy of Sciences (see above) has awarded $25 \mathrm{PhD}$ training fellowships to

women in sub-Saharan

Africa to study in centres of research excellence in other developing countries.

The novel programme, launched with the support of the Swedish International Development Authority (SIDA), is intended to help boost the participation of women in developing countries in science and technology. All the women, who are under the age of 30 , are due to start their fellowships in the next couple of months.

"There are many fewer women than men in the sciences [in the developing world]," says Lydia Makhubu, president of the Third World Organization for Women in Science. Makhubu's organization is an independent, non-profit body, hosted by the Third World Academy of Sciences, which aims to strengthen the participation of women in science-based development and decision-making

"The aim of the

programme is to develop a well trained cadre of women in science and technology leading to an increase in participation of women in science in these countries."

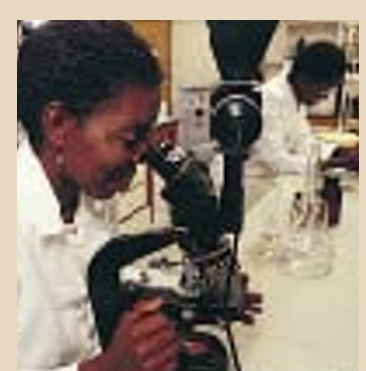

Women's work: researchers will train in other countries.

Makhubu, a chemist who is vice-chancellor of the University of Swaziland, says one advantage of training women within developing countries - rather than sending them to laboratories in industrialized countries - is that their experience gives them a better chance of finding work afterwards. They also "become more keenly aware of the problems in developing countries that need scientific solutions".

Candidates can choose to do some of their research training in their own countries, something that is crucial for those women who have homes and families they wish to return to. Areas of study will be primarily in the basic sciences.

If the programme is a success, the academy hopes to expand it with additional support from SIDA's Department for Research
Cooperation (SAREC). At present, the aid agency is providing US $\$ 200,000$ a year for the three-year programme.

A major factor behind SIDA's sponsorship of the programme was the Swedish government's recent introduction of a new development goal for the agency. According to SAREC official Afzal Sher, one of six development goals approved by the government a year ago "was that SAREC should work towards more gender equality".

"We are aware that the situation with regard to women in science in developing countries is very bad, so it's good to give special support earmarked for women," says Sher. "We have started in a relatively modest way, primarily for sub-Saharan African countries. This may be extended if the pilot works."

It will be several years before SAREC knows the quality of the candidates selected to work on the scheme, and it will take six years to find out whether the programme overall is working. But Makhubu is optimistic. "If you select 25 out of 110 applicants, then you have only the best and most highly motivated," she says. same form of guaranteed income as that already given to two other Trieste institutions: the ICTP and the International Centre for Genetic Engineering and Biotechnology.

"The idea launched by Salam 15 years ago has paid off in many ways in boosting the growth of scientific knowledge in the developing world, and Italy is proud of having been able to contribute to its success," says Facio Bonetti, head of the scientific and cultural division of the Italian foreign ministry.

According to Mohamed Hassan, the executive director of the academy since its creation, Italy's decision to formalize its support was partly prompted by the academy's success in raising money for an endowment fund from developing countries.

The fund, which was launched in 1993, is now more than one-third of the way towards reaching its target of $\$ 10$ million. Individual sums of $\$ 500,000$ have each been committed by Brazil, China, India, Nigeria and Kuwait, and other countries, including Egypt, Colombia and Senegal, have contributed smaller sums.

"The Italian government was able to see that the developing countries themselves are now committed to our activities," says Hassan. Eventually it is hoped that the academy will be able to use the income from its endowment fund to cover its running costs, allowing all other forms of income to go directly towards projects and other grants.

One of the main contributors towards these at present is the Swedish International Development Agency, which is currently committed to providing $\$ 200,000$ a year over three years through its technical assistance division, SAREC, towards a project for training women researchers in sub-Saharan Africa (see box).

Another scheme currently waiting in the wings, says Hassan, is the creation of networks of centres of research excellence in Third World countries. One possible network, involving institutions working in dry-land biodiversity, has recently been submitted for funding to the World Bank's Global Environment Facility.

José Israel Vargas, Brazil's minister of science and the president of TWAS, argues that its expanding activities since its foundation mean that the academy now finds itself "within sight of the vision presented by Salam at the academy's first meeting here in Trieste in 1985".

He adds: "With our operational budget about to be placed on solid ground, our long-term activities gaining in strength through contributions to the endowment fund, and the continued support of outside funding agencies, these are exciting times for TWAS."

DavidDickson 